\title{
Command: Individual or Collective? A Review of Anthony King's Command: The Twenty-First-Century General (Cambridge: Cambridge University Press, 2019)
}

\author{
Lawrence Freedman $^{1}$
}

Published online: 14 August 2019

(C) The Author(s) 2019

The word command comes from the Latin 'mandare', meaning to commit or entrust, from which we also get 'mandate'. The prefix 'con' gave it extra force. This meaning was sustained in French and eventually reached England around 1300. The verb 'to command' led to the noun 'command', which was from the start synonymous with an order. A command was an order that came with special authority and must be obeyed. Contemporary dictionary definitions still point to authoritative orders.

Orders to be obeyed without question came from God or a sovereign. Those ordered might have inner doubts and uncertainties but the orders must still be followed without question and followed well. Disobedience carried a risk of divine or corporeal punishment not only because of the importance of the order but also the nature of the authority. The right to command came down from the sovereign to ministers, generals and admirals. To challenge a command therefore was to challenge not only the wisdom of a particular instruction but also a whole structure of authority. Commanders could be removed from above but not from below. Once orders were routinely disobeyed authority was lost and could lead to mutiny at a low level or coups at a high.

Command was therefore not democratic but was strictly hierarchical. Objectives and the resources to meet them were handed down from one level to another. This is true still of most organisations, but many learn to cope with back and forth between the different levels when inappropriate or unobtainable goals have been set and inadequate resources have been allocated. In small organisations, decision-making can appear as a rolling seminar. But military organisations have a distinguishing feature and carry with them the language and procedures set down from earlier times when deference came more naturally. All military commands are concerned in some way with purposive violence. Once hostilities begin a commander's orders mean that people will kill and be killed. The special challenge of command lies in persuading people to act against their own instincts to survive and against the normal prohibitions against

An author's reply to this comment is available at https://doi.org/10.1007/s10767-019-09338-3.

Lawrence Freedman

lawrence.freedman@kcl.ac.uk

1 King's College London, London, UK 
murdering fellow humans. That is why we talk of orders rather than requests or suggestions. To disobey an order is insubordination; to walk away is desertion.

The responsibilities of command grow with rank but the immediate challenges may be at their most intense at the lowest levels, for example when a lieutenant must lead a platoon into a combat. The higher up the chain, the more remote the commander may be from actual fighting, and this might make it easier to give the orders. They may not always appreciate the demands placed on those below them who must hope that when they send back up the chain of command fresh intelligence and entreaties for extra reserves and resources these will be sympathetically received and acted upon. At the other extreme, there are the special issues raised by the command and control of nuclear weapons with direct lines between the senior political leadership and the operators.

As commanders at one level may have to act without waiting for fresh orders from the level above, military organisations spend a lot of time worrying about the circumstances in which orders should be ignored or at least amended by subordinate commanders. In the nuclear sphere, the issue of delegated authority is for obvious reasons particularly tricky. In addition, an effective commander must do much more than bark out orders, but must also organise and plan, formulate strategies and negotiate with allies, while inspiring and persuading those who must actually do the fighting. There is also a substantial literature addressing the qualities needed to be a good commander, and whether these are different when preparing for a possible war or in the conduct of war.

Because the concept of command is essentially anti-democratic and comes from a time of absolute rule, it has posed a challenge for democracies. A commander might command forces to overthrow a government on the grounds that it is weak, decadent or corrupt, or demand that fateful decisions be taken free of political interference. Hence, the emphasis put in by democracies to ensure that supreme command rests with the elected government. They still accept the hierarchical norm, with orders that must be obeyed as expressions of command, for without this, armed forces would struggle to function, but the goals they follow and the way they pursue them must come from the civilian authorities.

All these issues one way or another come up in any discussion of armed forces and war, from the motivation of troops to sustaining supply lines to devising strategies and implementing them to civil-military relations. There are many books on individual commanders and how they went about their business. Yet there are remarkably few offering a systematic investigation of the practice of command. The two best known are those by Marten van Creveld ${ }^{1}$ and John Keegan. ${ }^{2}$ Eliot Cohen made a major contribution with Supreme Command but that was from the perspective of political as opposed to military leadership. ${ }^{3}$

Keegan considered four individuals whom he took to represent exemplary forms of command. He started with Alexander as the classic ideal, avoiding any tension between the political and military strands of leadership by combining both in his person. He led from the front, ready for close combat. Next came Wellington and Grant, the first anti-heroic and the second un-heroic, although the distinction between the two was not wholly clear. Neither was inclined to great theatricality in the exercise of command. Both understood that they were not responsible for the political direction of war and that the front was the worst position from which to command a modern battle. Better to move back and forth behind their troops, making

\footnotetext{
${ }^{1}$ Command in War (Cambridge MA: Harvard University Press, 1985)

2 The Mask of Command (London: Pimlico, 1999)

${ }^{3}$ Eliot Cohen, Supreme Command: Soldiers, Statesmen, and Leadership in Wartime (New York: The Free Press, 20020
} 
their interventions only when they became necessary. Lastly, Keegan considered Adolf Hitler, occupying a category of his own, as 'fake-heroic'. He was completely in charge, militarily and politically, trading on his front-line experience in the Great War to gain credibility though now staying well away from the hard fighting. Though Keegan's was hardly a comprehensive typology, there was an underlying point. The sort of heroic command exemplified by Alexander was no longer possible, at least while leading great armies into battle, but nonetheless the individual qualities of the commanders made an enormous difference to the outcomes of war.

Van Creveld by contrast offered what he described as a 'happy' definition of command as 'a function that has to be exercised, more or less continuously, if the army is to exist and to operate'. ${ }^{4}$ There is so much to do to keep an army on the road, looking after their food and accommodation, their health and their supplies. As communications improved, with telegraph and radios, railroads and cars, then the function became ever more challenging. The advantage of this approach was as a reminder of how much must be done to keep an army available for war and that a purely operational approach can be misleading. The needs of a military organisation are many and various, from budgets to human resources, from intelligence gathering to operational plans, from advising on decisions to ensuring that they are implemented. A commander burnishing a heroic image might neglect these aspects of a job, and when operations are at their most intense might be forgiven for asking others to take care of them, but once a command position has been accepted a 'command regime' must surely follow.

Anthony King's book is the most substantial addition to the literature since these books. It is distinctive not only in the sociological perspective he brings to the topic but also his focus on major changes in the practice of command, even since the end of the Cold War. He also focuses on the command of armies, rather than navies or air forces. Most wars have been fought and won on land and so this approach allows for comparisons over time and between countries. He explores the changes since the start of the First World War by investigating the demands placed on two-star major generals commanding divisions. Here, King combines an innovative methodology with the historical sensibility that has always been the hallmark of his work. The chapters on how individual commanders went about their business from the start of the First World War to the present day are valuable accounts in themselves. His comparative perspective helps us understand better their personal strengths and weaknesses but also the impact of the operational circumstances and organizational expectations. Students of the contemporary British Army will welcome the account of General Nick Carter's 'epiphany' as he commanded ISAF's Regional Command South in Kandahar in 2009-2010 and realised the importance of a divisional level of command capable of coordinating all the different aspects of a contemporary operation. This became the basis for a major rethink of the army's command structures.

King's argument is that there has been a substantial shift from a more or less individualistic form of command as practiced in the twentieth century to something which he describes as 'collective command'. 'Today,' he notes, 'command collectives, consisting of commanders, their deputies, subordinates and staff bound together in dense, professionalised, decisionmaking communities, has displaced previously more individualised, intuitive systems'. If a senior commander insists on being part of the decision-making in every operational event then the risk is that decision-making becomes much slower without becoming better. General

${ }^{4}$ Van Creveld, op.cit., P.5 
Stanley McChrystal questioned his own value to the process of choosing targets to attack. 'Unless I had been tracking the target the previous night, I would usually know only what officer told me that morning .... My inclusion was a rubber stamp that slowed the process, and sometimes caused us to miss fleeting opportunities'.

There are many reasons for this but essentially the problem is that so many more tasks must be accomplished at this level of command than before. King draws on McCrystal's distinction between the challenges resulting from greater complication and those from greater complexity. With complication, there are 'many parts but those parts are joined, one to the next in relatively simple ways', whereas complexity 'occurs when the number of interactions between components increases dramatically' leading to greater unpredictability. ${ }^{5} \mathrm{He}$ calls other generals with recent command experience in aid when addressing this theme of greater complexity. For example, British General David Richards has written that the modern commander must be an 'entrepreneurial networker and communicator rather than a dictator'. ${ }^{6}$ He can also move beyond the military sphere. The same set of challenges faces chief executives of many modern organisations. It has been a long time since as 'captains of industry' they modelled themselves on war-time generals, but they still could assume hierarchy. Because of complexity, the trend favours forms of leadership that are 'distributed, pervasive, invited from all members, and instilled in the culture of successful enterprises" 7 .

Most large organisations need to manage large numbers of disparate activities and cope with vast amounts of incoming information coming in from the component parts as well as those in parallel or even more senior positions. All will have their own expectations about their needs and those of others. Because major operations are few and far between every move carries with it political sensitivities. Once the challenge was to coordinate infantry, artillery and cavalry, then came armoured brigades and air power. Now, cyber and information operations are part of the mix. All these activities have their own specialists and supply lines to be accommodated. In addition, the accuracy of modern weaponry means that there is now less tolerance, at least in western democracies, for armed force to be used as a blunt instrument so that civilian casualties are no more than unfortunate and regrettable 'collateral'. False steps are likely to be picked up by the media and magnified, as McChrystal himself found out to his cost. ${ }^{8}$ Some specific features of contemporary operations have added to the complexity, notably the formation of multi-national divisions. In these circumstances, it may be necessary to avoid giving offence to a coalition partner whose presence may be more valuable politically than militarily.

Hence the need for collective command:

Divisions and divisional operations have become increasingly heterogenous, involving deep integration of diverse joint and multinational elements; the geographic, temporal and functional span of command has also increased with complexity. Military missions have become deeply politicised and even at a low level military force has to be applied

\footnotetext{
${ }^{5}$ Stanley McChrystal, Team of Teams, (London: Penguin 2015), p. 57.

${ }^{6}$ David Richards 'The Art of Command in the Twenty First Century', in Julian Lindley French sand Yves Boyer, ed., The Oxford Handbook of War (Oxford: OUP, 2012), 382-4

7 Tony Zinni and Tony Koltz, Leadership Lessons from the battlefield to the boardroom, (London: Palgrave Macmillan, 2009), 51. Also 101-102

${ }^{8}$ In 2010 McChrystal's career came to an end as a result of remarks about the US's political leadership quoted in a profile in Rolling Stones magazine.
} 
with precision and proportion ...

Consequently in order to address increased coordination problems generals have been forced to distribute their decision-making authority to empowered subordinates, forming executive teams, closely united around a common understanding of the mission. ${ }^{9}$

To make his point he describes a modern command headquarters. Acknowledging that the Americans may err on the side of excess, to look after some 20,000 personnel a US Army Divisional HQ would have as many as 400 people, ten times the number required during the Second World War. Managing any organisation of this size would be a challenge for a chief executive to ensure that the different parts work effectively and as much as possibly in harmony.

But does this necessarily preclude hierarchy and individualism? Here, we come to an interesting problem, which King acknowledges with full candour. He quotes two of the most celebrated US generals of recent times, James Mattis and David Petraeus, disagreeing. According to Petraeus: 'There is one commander. He is the guy. Everyone else is in support of him'. Rupert Smith, a successful commander in the 1991 Gulf War and then in the Balkans, accepted that these process 'may be happening. But they shouldn't be'. ${ }^{10}$

King recognises that there are 'undeniable constants' and that generals remain the primary decision-makers. Ethically, they must accept legal and moral responsibility for the actions they order. Yet King suggests that this is not the reason for the resistance to the concept. Instead it stems from the offence it poses to a 'heroic self-image'. Instead of the 'revered personal martial qualities, like intelligence, bravery, courage, and nobility' he urges us to look at 'the more mundane mechanics of command itself.' He focuses not so much on commanders but on 'regimes of command'. ${ }^{11}$ In his introduction he also suggests another consideration at work. Taking a broader political perspective power has become 'collective, dispersed, and distributed'. He believes this to be a good thing, in contrast to those in the UK who have pushed for the country to leave the European Union, an institution which embodies these new forms of power. He is wary of self-styled 'heroic' leaders with simple messages, such as Donald Trump, and prefers more subtle forms of leadership, capable of 'building consensus and coordinating alliances and teams, deferring and disseminating authority to deputies and subordinates', less 'egotistical charisma' and more professionalism and teamwork. ${ }^{12}$ Clearly if this may now be the case with military command, where leadership has traditionally inclined to the heroic, then it might be even more so with all other forms of power relationships.

A lot here depends on how command is defined. King quotes the British Army definition of command which reflects the classical view. 'Command is the authority which an individual in military service lawfully exercises over subordinates by rank or assignment'. It 'embraces authority, responsibility and accountability. It has a legal and constitutional status - codified in Queen's Regulations. It is also vested in a commander by their superior. Authority enables an individual to influence events and order subordinates to implement decisions. ${ }^{, 13}$ But he also tends to describe command in organisational and not personal terms, commending van Creveld's view that 'stable and identifiable command regimes exist' as 'instructive'. ${ }^{14} \mathrm{King}$ however moves away from the focus on legitimacy by concentrating on decision-making as

\footnotetext{
${ }^{9}$ King, Command, p. 18

${ }^{10}$ Ibid, p. 21

11 Ibid., pp. 21-22.

${ }^{12} \mathrm{xv}-\mathrm{xvi}$

${ }^{13}$ Ministry of Defence, Joint Doctrine Publication 0-01 Joint Operations (Shrivenham: Development, Concepts and Doctrine Centre, 2011), p.3

${ }^{14}$ King, op.cit.,p. 16
} 
the means by which command is constituted. On this basis, the 'first, supreme and farreaching' decision of a divisional commander is to define the basic mission of the division. This is the 'prime executive act'. Having defined the mission, forces must then be organised, deployed and fought in its pursuit. ${ }^{15}$ The challenge for the commander, King suggests, lies in the inability in current conditions to monopolise decision-making. They have to distribute their authority, especially 'in the domain of mission management'.

It is not altogether clear here, however, why this is different from any situation in which a senior commander delegates command authority to subordinates. Command often takes the form of ordering people to give orders to others. It is not clear why this counts as collective as opposed to individual leadership. Strong and effective leadership may often depend on alliances and team work and not be at all heroic. Compared with Winston Churchill, his successor as Prime Minister, Clement Attlee hardly offered a heroic model. He appeared as chairman of a board of strong-minded individuals rather than as a directional leader. Yet he never shirked big and hard decisions. At times 'collective leadership' may be attempted but it rarely works and often results in a sometimes subtle but other times unseemly struggle for power. The risk with collectivity is that nobody is accountable for mistakes and failure, for moving decisions along and ensuring their implementation, for explaining to those above and below why a particular decision has been taken and what is expected to happen next. To recognise that someone must take legal and moral responsibility does not preclude collegiality or wide consultation.

Management theorists and even some managers may deride hierarchies and advocate flatter systems. In organisations of any size and complexity, however, there are still truly executive decisions to be made between competing options, each with their own costs, benefits and advocates. Resources are always scarce and someone has to make the allocations, which means that bits of the organisation are likely to be disappointed and even angry. Constant debate in search of consensus risks paralysis and drift. Promises of flat management can be a form of flattery, a pretence that everybody's view has some value and all can make equivalent contributions. It also makes everyone complicit if the risks have been underestimated and the results are calamitous. A good leader will forge a team, take note of dissenting views, accept that delegation is required and individuals must be trusted to get on with their jobs without constant interference from superiors. But if the team fails to perform it is the leader who will take the rap. One can therefore acknowledge the demands of complexity and the value of a mutually reinforcing team while also agreeing with the reservations as expressed to King by the generals he was interviewing.

There is a further issue with levels of command. The US and UK forces distinguish between the strategic, operational and tactical levels of command. Although these characterisations are in themselves dubious, and have broken down in the face of the demands of modern combat, ${ }^{16}$ there are clearly different levels of command responsibility from the platoon up to the division and beyond. At the lowest level, when a commander must be as brave as those being led, the heroic image may still be pertinent. Accounts of the Somme in 1916 or the Normandy Landings of June 1944 show how many officers were cut down at the front of their men, who were left leaderless at crucial moment. One of the more hotly debated moments of command during the Falklands campaign was the decision by 'Colonel ' $\mathrm{H}$ ' Jones of 2 Para to lead a charge into enemy positions, with the result that he was killed at once,

\footnotetext{
${ }^{15}$ Ibid., pp. 60-68

${ }^{16}$ I discuss this in my Strategy: A History (New York: OUP, 2013), pp., 206-7.
} 
instead of orchestrating the battle from a safer position. Moving higher up the chain of command issues arise about the degree to which it is permissible or possible for commanders to take initiatives. Even if they know the senior commander's intent they still may not be able to act unless they can persuade the senior commander to release supporting air power or gather vital intelligence. As King demonstrates these were the sort of issues that led the Carter to rethink the respective roles of the Brigade and the Division. In addition, even though there may be continuities in the size and fighting role of a Division, there have been shifts in its position in the chain of command. Thus Gary Sheffield describes 'High Command' as being 'characterised by interaction between military commanders and their political superiors', noting that while 'a divisional commander on the Somme in 1916 was not a high commander, his equivalent in Bosnia in 1997 most definitely would be'. ${ }^{17}$

This raises the question of whether King is really comparing like with like. He provides a vivid account of Bernard Montgomery's approach to divisional command while he was in charge of the 3rd Division in France until May 1940. Montgomery was a ruthless professional, making sure that officers knew to obey his orders and execute them effectively. It was on the basis of his performance in testing circumstances that he was promoted to Corps Command and eventually to taking charge of the 8th Army before becoming the Commander of 21st Army Group in Europe. King notes the controversies surrounding Montgomery's generalship are bound up with these later posts when he had to work within an alliance framework. Then he faced a number of the political challenges that a modern divisional commander might face. King also notes that Montgomery's first command was as a platoon commander in France in August 1914 when he led a charge brandishing his sword.

In all of these roles Montgomery was in command. If the comparative focus had been the platoon commander over the same period then one suspects that the continuities would have appeared as profound as the changes, while a focus on higher command might have led to a look at a division now but at least an Army in the First World War. Nonetheless, although there are therefore limits to what can be achieved with regard to a general theory of command simply by looking at the divisional level, this book does work as a means of exploring the impact of the changing character of warfare on command arrangements. King's achievement is to use his distinctive focus as a means of opening up questions about how senior commanders organised their headquarters and fight their battles. This is a book with which all students of command will have to engage.

Publisher's Note Springer Nature remains neutral with regard to jurisdictional claims in published maps and institutional affiliations.

Open Access This article is distributed under the terms of the Creative Commons Attribution 4.0 International License (http://creativecommons.org/licenses/by/4.0/), which permits unrestricted use, distribution, and reproduction in any medium, provided you give appropriate credit to the original author(s) and the source, provide a link to the Creative Commons license, and indicate if changes were made.

${ }^{17}$ Gary Sheffield, 'The Challenges of High Command in the Twentieth Century', in Gary Sheffield and Geoffrey Till, ed., The Challenges of High Command: The British Experience, (London: Palgrave, Macmillan, 2003), 1 